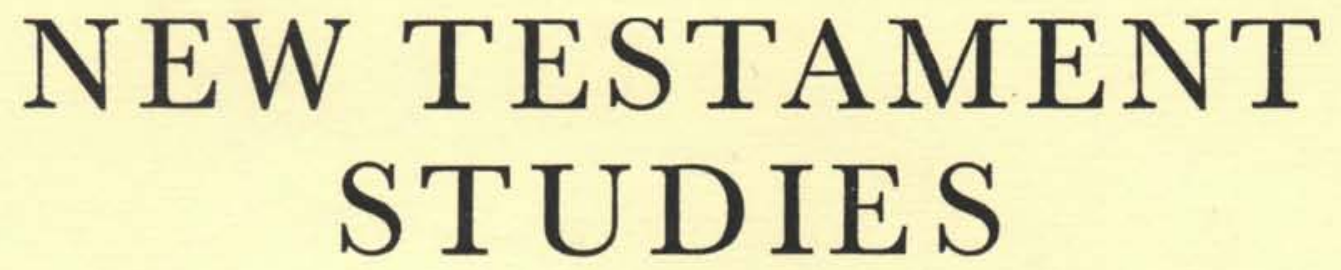

AN INTERNATIONAL JOURNAL PUBLISHED QUARTERLY UNDER THE AUSPICES OF

STUDIORUM NOVI TESTAMENTI SOCIETAS

EDITORIAL BOARD FOR I $974-75$

THE PRESIDENT AND SECRETARY OF THE SOCIETY $e x$ officio

PROF. DR W. SCHRAGE (Bonn)

PROF. P. BENOIT (Jerusalem, Israel)

PROF. DR G. STRECKER (Bovenden, BRD)

L'ABBÉ J. CARMignac (Paris)
PROF. G. W. MACRAE (Cambridge, Mass.) PROF. DR S. AALEN (Oslo, Norway)

REV. PROF. DR R. A. KRAFT

(Roslyn, Pa., U.S.A.)

PROF. DR M. BOUTTIER (Montpellier, France)

CHAIRMAN OF THE BOARD: vacant

EDITOR AND SECRETARY OF THE BOARD

REV. PROF. M. BLACK (St Andrews)

ASSOGiate editor: Rev. PROF. R. MCL. Wilson (St Andrews)

VoL. 21

JULY 1975

No. 4

\title{
ARTICLES
}

Rt Rev. Dr J. A. T. Robinson (Cambridge, England). The Parable of the Wicked Husbandmen: A Test of Synoptic Relationships

DR Theol. Hans HüBneR (Erkrath-Unterbach, Germany/BRD). Existentiale Interpretation der Paulinischen 'Gerechtigkeit Gottes'

Rev. Professor R. T. Fortna (Poughkeepsie, N.Y., U.S.A.). Christology in the Fourth Gospel: Redaction-Critical Perspectives

Professor Dr H.-M. Schenke (Berlin, Germany/DDR). Das Weiterwirken des Paulus und die Pflege seines Erbes durch die Paulus-Schule

\section{SHORT STUDIES}

REV. W. E. MOORE (Manchester, England). BIAZW, APTAZW and Cognates in Josephus

Professor J. D. M. Derrett (London, England). Cursing Jesus (I Cor. xii. 3): The Jews as Religious 'Persecutors'

Dr D. J. Rowston (Unley Park, S.A., Australia). The Most Neglected Book in the New Testament

Rev. P. W. BArnetr (Adelaide, S.A., Australia), 'Under Tiberius all was Quiet' $\quad 564$

\section{CAMBRIDGE UNIVERSITY PRESS}

Bentley House, 200 Euston Road, London NwI 2DB

32 East 57th Street, New York, N.Y. 10022

I975 subscription per volume $£ 9.50$ net (US \$28.50) (4 parts) https://doi.org/10.1017/S0028688500009954 Published online by Cambridge University Press $\$$ Single parts \&3.00) 


\section{GONTRIBUTIONS}

Contributions, which may be in English, French or German, should be submitted in typescript to Professor M. BLACK, University of St Andrews, St Mary's College, St Andrews, Fife.

Each contributor will receive a copy of the number and 25 off-prints of his article free of charge.

Authors will be responsible for all alterations to proofs which exceed $20 \%$ of the cost of composition.

\section{MONOGRAPH SERIES}

In view of the increasing number of typescripts which are being received for possible publication, those who wish to submit work are asked not to do so without first consulting the Editors who will be glad to advise about format, length and possible date of publication if the work can be accepted.

(C) CAMBRIDGE UNIVERSITY PRESS, I 975

\section{PERMISSIONS}

For permission to reproduce material from New Testament Studies, please apply to the London or New York office of Cambridge University Press.

\section{SUBSCRIPTIONS}

New Testament Studies is published quarterly by Cambridge University Press, P.O. Box 92, London NWI 2 D B and 32 East 57th Street, New York, N.Y.I0022. Single parts cost $£ 3.00$ net (US $\$ 9.00$ in the U.S.A. and Canada), plus postage. Four parts form a volume. The 1975 subscription price of a volume (which includes postage) is $£ 9.50$ net (US $\$ 28.50$ in the U.S.A. and Canada).

Members of Studiorum Novi Testamenti Societas receive New Testament Studies at special terms.

Copies of New Testament Studies for subscribers in the United States of America are sent by air to New York to arrive with minimum delay.

Second class postage paid at New York, N.Y. 